\title{
INTRODUCTION TO THE BOOK OF ESTHER (BIBLE WEEK, OSNABRÜCK, 28 JULY-3 AUGUST 2013)
}

\author{
Jonathan Magonet
}

The Book of Esther hardly needs an introduction. However, at first glance it is easy to dismiss it as belonging to the kind of extravagant storytelling we associate with the oriental world, something out of the 'Thousand and One Nights'. Nevertheless, we must be careful not to project our western prejudices onto this kind of literature, which, in its own way, seeks to instruct as well as entertain. Within the Hebrew Bible the Book of Esther might be classified as wisdom literature, illustrating how a wise man turns the tables on his deadly enemy in the struggle for power in a world of palace intrigues. Moreover, it is especially significant as the only book to be set in the diaspora, exploring the implications of this new reality of exile with its opportunities and dangers.

For modern sensitivities it has offered a fascinating, if problematic, reflection on feminist issues. Earlier commentators saw Queen Vashti as the real heroine of the book, refusing to obey her husband's summons to be displayed before his men friends. In contrast, Esther appears to be totally submissive, first to the will of Mordecai and then to the king. It is only at the end that she becomes the prime mover of events. But Vashti's rebellion ends in a heroic failure, whereas Esther's apparent submissiveness ends in victory. Which model is one to follow? More recently Klara Butting has used the Esther and Joseph stories to explore the relationship between the totalitarianism displayed in the regime of an Ahasuerus and both sexism and anti-Semitism. ${ }^{1}$

For Jews the Book of Esther is associated with the festival of Purim and the carnival-like atmosphere of that festival. Nevertheless it raised embarrassing problems for the rabbis. How could a nice Jewish girl like Esther marry a Gentile king? One rabbi proposed the use of a doppelgänger who replaced her in the marital bed. How did she maintain normal Jewish religious practices, such as eating kosher food, while in the palace? They did credit her with inventing an ingenious method to enable her to keep track of when it was Shabbat - she named her seven serving girls after the days of the week, so always knew what to do when it was the turn of the girl called Shabbat. There is an odd, and decidedly anachronistic, modern reflection on such concerns in the beautiful Sabbath prayer from the musical Fiddler on the Roof. 
May you be like Ruth and like Esther

May you be deserving of praise.

Strengthen them, O Lord,

And keep them from the strangers' ways.

These words do not follow the traditional language for blessing daughters which wishes them to be like the matriarchs Sarah, Rebecca, Rachel and Leah. For Jewish life in Czarist Russia at the turn of the twentieth century, where Fiddler on the Roof is set, such a change would have been shocking, because these alternative names represent two highly problematic situations for that traditional society. After all, Ruth was a convert to Judaism and Esther married out! However, for the writers and composer of the musical living in today's United States, with considerable Jewish assimilation to 'the strangers' ways' and a high level of intermarriage, Ruth and Esther may indeed have become exemplary role models.

For Christians the Book of Esther seems to be even more problematic, particularly because Purim does not feature in the Christian religious calendar. Early commentators felt the need to read it as an allegory. Inevitably one thinks of Martin Luther's alleged condemnation of the book in his Table Talk (24), alleged because there are questions about the correct understanding of his views. Nevertheless, the International Standard Bible Encyclopaedia says: ${ }^{2}$

The opponents of the Book of Esther may undoubtedly boast that Martin Luther headed the attack. In his Table-Talk he declared that he was so hostile 'to the Book of Esther that I would it did not exist; for it Judaizes too much, and has in it a great deal of heathenish naughtiness.' His remark in his reply to Erasmus shows that this was his deliberate judgment. Referring to Esther, he says that, though the Jews have it in their Canon, 'it is more worthy than all' the apocryphal books 'of being excluded from the Canon.'

It is understandable that certain aspects of the book, including its 'heathenish naughtiness', could provide real challenges to Christian understanding. However, more seriously, until relatively recently, Christian Bible commentators could use the Book of Esther to express what can only be described as strongly anti-Semitic sentiments, such as describing the book as: 'the product of a nationalistic spirit, seeking revenge upon those who persecute the Jews, which has lost all understanding of the demands and obligations of Yahwism'. ${ }^{3}$ This is a difficult legacy that Christians must address today.

But if we approach the book as a literary creation, a kind of historical novella, a rabbinic question may be helpful: was Ahasuerus a fool or was he wise? (Megillah 12a). On the face of it he was a fool. Defied by his first wife, Vashti, he ends up being manipulated by his second wife, Esther. He 
is surrounded by advisers whose advice leads to absurd decisions and laws. And yet, in the kind of autocratic kingdom that Ahasuerus rules, he is himself permanently endangered - Mordechai saves him from a plot by two of his close servants to kill him and we are given a glimpse of Haman's long-term ambitions. So can we see in the events that unfold the king's own concerns about survival? When are the coincidences of the plot more than coincidences?

Another area to bear in mind, considering the late composition of the book, is the extent to which it contains echoes of earlier Biblical materials.

Of course, the great central question in the book is the apparent absence of God. Some see in the way things finally resolve that God is acting behind the scenes. It is also argued that the way the actual scroll might be mishandled during the riotous reading of the Megillah during the Purim celebration in synagogue led the author to avoid the explicit use of the name of God within the text. But even if that is the case, the absence of God in a Biblical book poses questions about the very nature of the Hebrew Bible itself. Whatever else the book of Esther offers, it takes us on a first tentative step into the many dimensions of exile.

\section{Notes}

1. Klara Butting, 'Esther: A New Interpretation of the Joseph Story in the Fight against Antisemitism and Sexism' in A Feminist Companion to the Bible: Ruth and Esther, ed. Athalya Brenner, Sheffield Academic Press 1999, 239-249.

2. 'Esther, Book of', International Standard Bible Encyclopaedia, vol. 2, 1007.

3. Georg Fohrer, Introduction to the Old Testament, trans. David E. Green, Nashville: Abingdon 1968, 253. Quoted, with other examples, in Frederic W. Bush, 'The Book of Esther: Opus Non Gratum in the Christian Canon', Bulletin for Biblical Research 8, 1998, 39-54, 40. 